\title{
Trade union membership and paid vacation in Germany
}

\author{
Laszlo Goerke ${ }^{1,2,3^{*}}$, Sabrina Jeworrek ${ }^{1}$ and Markus Pannenberg ${ }^{2,4,5}$
}

\footnotetext{
* Correspondence: goerke@iaaeu.de ${ }^{1}$ IAAEU - Trier University, Institute for Labour Law and Industrial Relations in the European Union, Campus II, D-54286 Trier, Germany 2IZA, Bonn, Germany Full list of author information is available at the end of the article
}

\author{
Abstract \\ In Germany, dependent employees take almost 30 days of paid vacation annually. \\ We enquire whether an individual's trade union membership affects the duration of \\ vacation. Using data from the German Socio-Economic Panel (SOEP) for the period \\ 1985 to 2010 and employing pooled OLS-estimators, we find that being a union \\ member goes along with almost one additional day of vacation per year. Estimations \\ exploiting the panel structure of our data suggest that a smaller part of this vacation \\ differential can be due to the union membership status, while self-selection effects \\ play a more important role. \\ JEL Classifications: J 22; J 33; J 51; J 81 \\ Keywords: German Socio-Economic Panel (SOEP); Paid vacation; Trade union \\ membership
}

\section{Springer}

\section{Introduction}

Annual working time varies greatly across countries. In 2012, employees worked about 1,800 hours in the United States and 1,650 hours in the United Kingdom, while the corresponding figure was 1,400 for Germany (see OECD 2013, Table K, which includes full- and part-time workers). A substantial part of this gap is due to differences in vacation time. According to the European Union Working Time Directive, there is a statutory minimum of paid annual vacation of four weeks, whereas in the United States there are no such regulations (Ray et al. 2013). Furthermore, the actual duration of paid vacation in Germany of almost six weeks per annum exceeds the statutory entitlement substantially and is about twice as high as in the United States and also greater than in the United Kingdom. ${ }^{1}$

A reduction of working time has long been a prominent objective of trade unions. However, there is little knowledge about the success of such endeavours. The few studies analysing empirically the strength of trade unions and weekly or annual working time provide some, but certainly no conclusive evidence of a negative correlation (cf., inter alia, Burgoon and Baxandall 2004, Alesina et al. 2005, Faggio and Nickell 2007, Causa 2009, Berger and Heylen 2011, and Oh et al. 2012). With respect to vacation time, the evidence is even scarcer. It suggests that individuals covered by collective bargaining agreements enjoy longer vacations in the United States (Buckley 1989, Buchmueller et al. 2004) and Japan (Ohtake 2003) and higher vacation entitlements in Great Britain (Green 1997, Bryan 2006), while the evidence for Canada is

(c) 2015 Goerke et al. Open Access This article is distributed under the terms of the Creative Commons Attribution 4.0 International License (http://creativecommons.org/licenses/by/4.0/), which permits unrestricted use, distribution, and reproduction in any medium, provided you give appropriate credit to the original author(s) and the source, provide a link to the Creative Commons license, and indicate if changes were made. 
mixed (Fakih 2014, Shi and Skuterud 2015). ${ }^{2}$ Furthermore, individual union membership enhances vacation entitlements in Great Britain (Bryson and Forth 2011, p. 267 f) and both entitlements and the days of vacation taken in the United States (Green and Potepan 1988, Buchmueller et al. 2004, Maume 2006, Altonji and Usui 2007). More precisely, the estimated coefficients suggest that union members take between half and a full week of vacation more than non-members in the United States. Finally, Alesina et al. (2005) investigate the distinct development of working time in the United States and Europe. They also look at paid vacation of full-time employed heads of household and show that union members take about 3 days paid vacation per annum more than non-members in Germany in 2001. The authors also establish a positive correlation for the United States. However, none of the analyses thoroughly tackles the issue of whether the observed membership effect on vacation can be viewed as causal or is due to the selection of vacation-prone individuals into trade unions.

A further feature of the extant studies is that they predominantly refer to Great Britain and the United States. In both countries union density and coverage by collective bargaining agreements coincide to a large extent in the private sector. ${ }^{3}$ Therefore, trade unions may be less concerned with free-riding activities of covered non-members than they have to be in a country such as Germany, where coverage by collective bargaining substantially exceeds union density. Consequently, in this contribution we empirically analyse the relationship between individual trade union membership and the number of vacation days taken in Germany and investigate whether the observed correlation is due to selection effects. Accordingly, we do contribute to the literature on the consequences of an individual's union membership, but not on trade union coverage effects.

There are numerous reasons why individual union membership can affect the duration of paid vacation. First, there is evidence that trade unions attempt to extend entitlements laid down in collective contracts solely for its members. For example, one of the largest unions worldwide, the German public sector union ver.di, was able to bargain an extra two days of paid vacation for some of its members. ${ }^{4}$ Since many employees covered by the collective contract do not belong to ver.di, these extra vacation days are related to an individual's membership status. Second, in some industrial relations settings, only union members are legally able to enforce collectively negotiated vacation entitlements in excess of the legal minimum. Third, it can be argued that trade unions provide their members with better information about vacation entitlements and the conditions under which employees can enforce them. ${ }^{5}$ Fourth, union members may be better able to establish working conditions in accordance with their preferences than non-members, for example, with regard to working hours, shift work and absence periods. Such greater congruence between desired and actual conditions would reduce the need to utilise vacation in order to reconcile a mismatch. Finally, the relationship between vacation and union membership can also be viewed from an exit-voice perspective. If going on vacation is viewed as a short-term exit, members could be expected to take fewer vacation days because the trade union provides a voice mechanism. However, absence from work could also be interpreted as a voice mechanism. Since members have to fear reprisals less than non-members, given that unions provide them with legal advice and representation, the voice mechanism 'vacation' may be employed more extensively by members. All in all, the majority of arguments suggest that trade union members can take more days of paid vacation than non-members. 
A positive correlation between union membership and vacation could also be observed for other reasons than those enumerated above. First, people may have characteristics unobservable to the researcher which make them both more likely to be a union member and to take more paid vacation. Second, union membership could be an empirical proxy for institutional features of the industrial relations system which are associated with higher vacations. In Germany, this may be the case because employees who work in firms covered by collective bargaining or plants in which a works council exists obtain more paid vacation than employees who work in otherwise similar firms or plants without such institutions.

In order to analyse the relationship between individual trade union membership and the number of paid vacation days taken, we use data from the German Socio-Economic Panel (SOEP) for the period 1985 to 2010. Employing a pooled OLS-estimator, we show that trade union members have almost one day more vacation than non-members annually, controlling for a host of demographic and workplace related variables. Assuming 200 working days per year, the monetary equivalent of the additional day of vacation is about $0.5 \%$ of annual gross income and would cover $50 \%$ of the union membership fee. This suggests that additional vacation could represent a substantial private gain from individual trade union membership which limits free-riding behaviour.

This finding is all the more remarkable because previous analyses have not been able to establish a union membership wage effect in Germany (cf., for example, Schmidt and Zimmermann 1991, Fitzenberger et al. 1999, and Goerke and Pannenberg 2004). Moreover, there are only few studies in which other differences have been looked at. Goerke and Pannenberg (2011), for example, show that trade union members in Western Germany are less likely to be dismissed individually than non-members. In addition, Goerke and Pannenberg (2015) estimate that union members take about a day more of sickness-related absence annually than non-members. This effect is quantitatively comparable to the estimated OLS-vacation differential between members and non-members.

To cater for the concern that the observed vacation effect arises because individuals select themselves into union membership due to time invariant unobserved characteristics, we additionally employ linear fixed-effects specifications. The coefficients remain positive but become considerably smaller in magnitude (less than 0.45 ) and are also estimated less precisely, i.e. only significantly positive at the $10 \%$-level in two out of three of our preferred specifications. This suggests that the largest part of the pooled OLS union membership-specific differential of almost one day is due to selection into membership. This interpretation is supported by the results from nonlinear correlatedrandom effects specifications.

We also deal with the second issue, namely that union membership represents an empirical proxy for high vacation entitlements due, for example, to firm characteristics. To this end, we initially control for firm size and industry effects in our empirical specifications. Furthermore, we consider a subgroup of firms which are overwhelmingly covered by collective bargaining and almost all have a works council. Additionally, we present estimates of the relationship between individual union membership and the number of vacation days taken for a subsample of years for which we have information about vacation entitlements. Such entitlements are also likely to reflect collective 
bargaining effects. Finally, we restrict our sample to employees who stay with their employer in order to account for time-invariant, unobservable firm characteristics in fixed-effects specifications. We find significantly positive correlations between individual trade union membership and paid vacation in all pooled OLS specifications and a marginally insignificant estimated coefficient of individual membership in the FE specification of the stayer sample. As a further robustness check, we distinguish between the private and public sector on the one hand and between services and industry on the other. The findings indicate that the union membership effect on vacations is primarily a private sector phenomenon and quantitatively stronger in services than in the industrial sector. Finally, we explore the impact of experience.

Relating these insights to the literature, our contribution is threefold: To the best of our knowledge, we are the first to thoroughly investigate the relationship between individual trade union membership and vacations days for a cooperative industrial relations system, such as the German one. Second, the institutional setting in Germany ensures that we identify the impact of an individual's membership in a trade union. This is in contrast to, for example, the United States, where union membership and collective bargaining generally coincide. Third, combining our findings from fixed-effects and correlated-random-effects specifications for a variety of specifications suggests that the larger part of the estimated OLS membership vacation differential is due to selfselection. Individuals who have stronger preferences for vacation are more likely to be a trade union member or they exhibit other unobserved characteristics which lead to a greater likelihood of being a union member and to a more extensive use of vacation entitlements.

For trade unions, our findings may be regarded as bad news. First, the panel estimates suggest that union membership can increase vacation by at most half a day annually. Such an effect could only help to establish a relatively small private benefit from individual membership, equivalent to less than a quarter of the membership fee. Second, if union members take an extra day of vacation, irrespective of whether this is a true membership or a selection effect, their effective labour costs will be higher than those of non-members by about $0.5 \%$, and firms will have fewer incentives to employ them, ceteris paribus.

The further paper develops as follows. In the next section, we describe the German institutional setting, while in Section 3, we outline the available data and the empirical strategy. Section 4 provides some descriptive results as well as the main findings of our regression analyses. In Section 5, we present various robustness checks. Section 6 concludes.

\section{Institutional background}

\subsection{Trade union membership and industrial relations in Germany}

In 1985, about $35 \%$ of dependent employees belonged to a trade union in the former Federal Republic of Germany, i.e. the western part of the country. This fraction has fallen to about $18 \%$ in the re-unified country in 2011. Moreover, union density in the public sector is about twice the rate in the private sector (cf. Visser 2013). Union members generally pay a tax-deductible membership fee of $1 \%$ of their gross wage. In exchange, they are entitled to strike pay, legal advice, and support by union officials in case of conflicts with their employers. Relative to the average working population, trade 
union members are more often male and blue-collar workers, have higher tenure and work in larger firms. Additionally, they are more likely to be employed in firms covered by collective bargaining agreements and having a works council, inter alia because these institutions are more prevalent in large establishments (cf., f.e., Goerke and Pannenberg 2004, Schnabel and Wagner 2007, Fitzenberger et al. 2011).

These two features, collective bargaining and works councils, characterise the dual structure of the German system of industrial relations. Collective bargaining agreements determine wages and overall working conditions, including vacation entitlements, mainly at the industry level, while works councils constitute a co-determination body at the plant level. According to the Works Constitution Act as the relevant law, works councils can be set up in private sector establishments with at least five permanent employees. They have information, consultation and codetermination rights which become more extensive with firm size. However, works councils are generally not allowed to bargain over issues already dealt with in collective bargaining agreements, such as wages and vacation entitlements. In addition to works councils, there are so-called personnel councils, which cover most public sector employees. They have similar or more extensive rights than their private sector counterparts.

In 2012, bargaining coverage in Germany was almost 60\%, while wages and working conditions for a further $20 \%$ of employees were determined in line with collective bargaining agreements, either because individual contracts referred to collective agreements or employers voluntarily applied their provisions. Ten years earlier, coverage had been about 10 percentage points higher. In the public sector, almost all employees are subject to collective negotiations (Ellguth and Kohaut 2005, 2013, Visser 2013). The regulations contained in collective bargaining agreements are legally binding only for the signatories of the respective contracts, that is, for members of trade unions who work in firms which have signed a firm-level contract or which belong to an employer association that has concluded an industry-level contract. Consequently, a large majority of the employees covered by such agreements does not belong to a trade union. Nonetheless, firms generally apply collective agreements to all employees irrespective of an individual's union membership status, which may not even be known to the employer. Therefore, the remuneration of employees, working time arrangements and many non-wage compensation elements are determined by collective bargaining for an overwhelming fraction of privatesector employees.

The opportunities to limit collective bargaining outcomes to trade union members, as described with respect to vacation entitlements in the Introduction, are limited by law. Closed-shop arrangements, for example, are not allowed and the constitution grants all individuals the right to set up trade unions, or to abstain from doing so, and declares all steps to obstruct this right as illegal. Additionally, the Non-discrimination Law (Allgemeines Gleichbehandlungsgesetz), which implements requirements originating from various European Union directives, explicitly forbids a disadvantageous treatment of trade union members. By analogy, also a differential treatment of non-members is restricted. In particular, it is not possible to prohibit firms from extending potentially preferential regulations for members of a trade union to non-members. 


\subsection{Paid vacation}

In the European Union, maximum working hours and the minimum duration of paid vacation are laid down in the European Working Time Directive (2003/88/EC) from 2003. This directive, inter alia, requires four weeks of paid annual leave. In Germany, the Federal Vacation Law (Bundesurlaubsgesetz) establishes entitlements which are consistent with the Directive. The law was introduced in 1963 and created an entitlement to 18 days of paid vacation on the basis of six working days per week. This minimum overall vacation period was raised to 4 weeks in 1994 . The Federal Vacation Law rules out the possibility to substitute additional wage payments for such vacation entitlements if they are not used, unless the employment relationship is terminated. For the first 6 months of an employment contract, often matching the probationary period, the right to take paid vacation only exists on a pro rata basis. Since vacation entitlements are based on calendar years, employees can generally use remaining entitlements in the first months of the subsequent year. In addition to paid vacation entitlements, there are between 9 and 13 public holidays in Germany. Their number varies across federal states and regions and also depends on calendar dates (see Ray et al. 2013).

Against this legal background, actual working time arrangements are codified in individual contracts or collective bargaining agreements. The scarce empirical evidence suggests that paid vacation entitlements agreed upon in collective bargaining contracts are often close or equal to 30 days per annum (WSI 2014). With regard to restrictions on vacations within the first months of an employment relationship, individual contractual agreements or collectively bargained clauses which improve the employees' opportunities to take paid vacation are always feasible. Consequently, the legal regulations outlined above constitute a constraint for a relatively small group of employees.

\section{Data description and empirical strategy}

To investigate the influence of individual trade union membership on vacation leave, we use the German Socio-Economic Panel (SOEP). The SOEP is a nationally representative survey conducted each year since 1984 with about 20,000 participants belonging to approximately 11,000 households in recent waves. ${ }^{6}$ The (retrospective) question on vacation days has been asked from 1985 to 1990, as well as in the years 2000, 2005 and 2010 and reads as follows: "How many days of vacation did you actually take last year?". Accordingly, the SOEP provides data on paid vacation from 1984 to 1989 and for the years 1999, 2004 and 2009. Information on individual trade union membership is available for 1985, 1989, 1993, 1998, 2001, 2003, 2007 and 2011. Table 5 in the Appendix summarises this temporal aspect of the data.

Apparently, we can use responses for the years 1985 and 1989 directly. However, when exclusively concentrating on these years, we would leave unused the data on vacation from other years. In order to avoid this loss of information, we impute the information on union membership and take advantage of the panel dimension of our data. In Section 5, we additionally report findings from two different complete case analyses.

We employ two versions of a simple imputation (SI) strategy and, additionally, a multiple imputation (MI) approach. First, in addition to the years 1985 and 1989, we use union membership information only if a respondent has answered the relevant question identically in the closest waves before and after the respective wave containing information on vacation. We denote this procedure as simple imputation 1 (SI 1). For example, 
an observation from the year 1986 is used only if the respondent provided valid and identical union membership status information in the survey years 1985 and 1989. In this case, we assume that the particular membership status also holds for interjacent years, such as 1986. A second, less restrictive simple imputation strategy, labelled simple imputation 2 (SI 2), allows for changes in union membership status between two waves which comprise the relevant information. In particular, we assume that those respondents change their membership status in the middle of the corresponding time interval, who state to be a member in one wave and no longer to belong to a trade union in the subsequent wave with the pertinent information, and vice versa. ${ }^{8}$ Taking again the example of the years 1985 and 1989, this strategy implies that a change is assumed to take place in 1987. For the year 1986, we consequently use the information received in 1985, whereas we employ the membership status observed in 1989 in the years 1987 and 1988. Furthermore, the simple imputation approach 2 (SI 2) implies that we can use information from respondents who provide information on membership only in some waves by imputing the status from the most adjacent waves. Accordingly, an individual would, for example, belong to the sample from 1987 to 1989 if we only have the membership information in 1989. These two simple strategies allow imputing the union membership status for about 80\% (SI 1) to more than $95 \%$ (SI 2) of the observations with information about the number of vacation days taken and all covariates described later on in this chapter (see Table 6 in the Appendix).

Second, we multiply impute the missing values for the years 1986 to 1988, 1999, 2004 and 2009 based on the complete case information on individual union membership and paid vacation information in 1985 and 1989 (denoted as multiple imputation, MI). In this case, we use all covariates and the respective outcome variable of the analysis models as well as party preferences, intensity of party preferences, factor variables of the survey weights (i.e. quintiles) as well as individual information on union membership status in other SOEP waves in our binary logit imputation models. ${ }^{9}$ Since preliminary regression exercises indicated potential gender-specific parameter heterogeneity, we separately impute the missing union membership information for both gender groups. This allows the association between paid vacation and union membership to differ between males and females. The number of imputations is $\mathrm{m}=60$.

An important determinant of the actual duration of vacation is the vacation entitlement (cf. Ohtake 2003, Altonji and Usui 2007 and Schnitzlein 2012). Given the fact that such entitlements are an important component of collective bargaining agreements in Germany, which apply to 60 to $80 \%$ of all employees, they also indirectly capture the impact of such agreements. The information with respect to vacation entitlements is only available for the waves 2000, 2005 and 2010 (see Table 5 in the Appendix) and can, hence, not be employed in the multiple imputation procedure. Contrary to the question relating to vacation days taken, the enquiry concerning entitlements does not explicitly refer to the previous year. Since both questions are asked consecutively in the SOEP questionnaire, it is nevertheless likely that survey participants refer to the same year when answering those questions. ${ }^{10}$

Our sample consists of regular employees with a minimum tenure of 12 months. By imposing such a lower boundary on tenure we can eliminate most of those employees from the sample who have not yet completed their probationary period and may only be able to make limited use of their vacation entitlement. Additionally, we exclude civil 
servants (Beamte), for whom different legal regulations apply than for regular employees, as well as self-employed. Finally, explicit information with regard to a worker's coverage by a collective bargaining agreement is only available in the SOEP data for 1995, while respondents have been asked about the existence of a works council in 2001, 2006 and 2011. Therefore, we can only indirectly ascertain the effects of these institutions on vacation (cf. Section 5).

Since we have unbalanced panel data at hand, we start with a standard linear unobserved effects panel model:

$$
v_{i t}=x_{i t} \beta+u m_{i t} \gamma+c_{i}+\varepsilon_{i t}
$$

In equation (1), $v_{i t}$ is the number of vacation days taken by individual $i$ in period $t$. The covariate vector $x_{i t}$ consists of variables such as age, dummy variables for being foreign, having completed an apprenticeship, obtained a university degree, working part-time, having a temporary contract, and being a white-collar employee, as well as tenure and tenure squared. Furthermore, $x_{i t}$ includes different firm size categories (20 to 199, 200 to 1999, and 2000 or more employees) and the regional unemployment rate at the level of the federal state (Bundesland). Additionally, we incorporate dummy variables capturing the survey year and the sector (NACE 1-digit) in which the respondent works. Our main variable of interest in equation (1) is denoted by $u m_{i t}$, indicating an individual's union membership status. The unobserved individual effect is denoted as $c_{i}$ and $\varepsilon_{i t}$ is the idiosyncratic error term.

In a first step, we estimate the parameters of equation (1) by pooled OLS under the assumption that $E\left(x_{i t}^{\prime} u_{i t}\right)=0$, where $u_{i t}=c_{i}+\varepsilon_{i t}$. In a second step, we apply the linear fixed-effects estimator (FE) under the assumption that $E\left(x_{i s}^{\prime} u_{i t}\right)=0$ for all $\mathrm{s}$ and $\mathrm{t}$. The FE estimator allows for $c_{i}$ to be correlated with all elements of $x_{i t}$ and $u m_{i t}$.

Our dependent variable is a count variable, such that the use of count data panel models may be advocated. Therefore, we also employ the following correlated-randomeffects Poisson model (CRE_Poisson):

$$
E\left(v_{i t} \mid x_{i t}, c_{i}\right)=c_{i} \exp \left(x_{i t} \beta+u m_{i t} \gamma\right) \text { and } c_{i}=\exp \left(\psi+\bar{x}_{i} \xi+\overline{u m}_{i} \tau\right) a_{i},
$$

where $\bar{x}_{i}$ is a vector of individual-specific means of some time-varying covariates, $\overline{u m}_{i}$ is the individual-specific average of union membership status and $a_{i}$ is independent of $x_{i}$ with unit mean. We apply a generalised estimating equations (GEE) approach with exchangeable working correlation to estimate the average partial effects (APE) of the variables of interest (Wooldridge 2013). The estimated APEs then allow for a direct comparison with the FE-coefficients. SOEP weights are used in all regressions to account for survey design as well as panel attrition.

\section{Results}

Overall union density in our multiply imputed data set is about $29 \%$. On average, $35.4 \%$ of male employees are trade union members, whereas the membership rate is $19.6 \%$ for female employees. This ratio has not changed much over time. The information is consistent with data from other sources since in 2013 more than two thirds of the 6 million members of the largest trade union federation in Germany, Deutscher Gewerkschaftsbund (DGB), were male. ${ }^{11}$ Table 1 reports some additional descriptive statistics differentiated by gender and trade union membership status. 
Table 1 Descriptive statistics

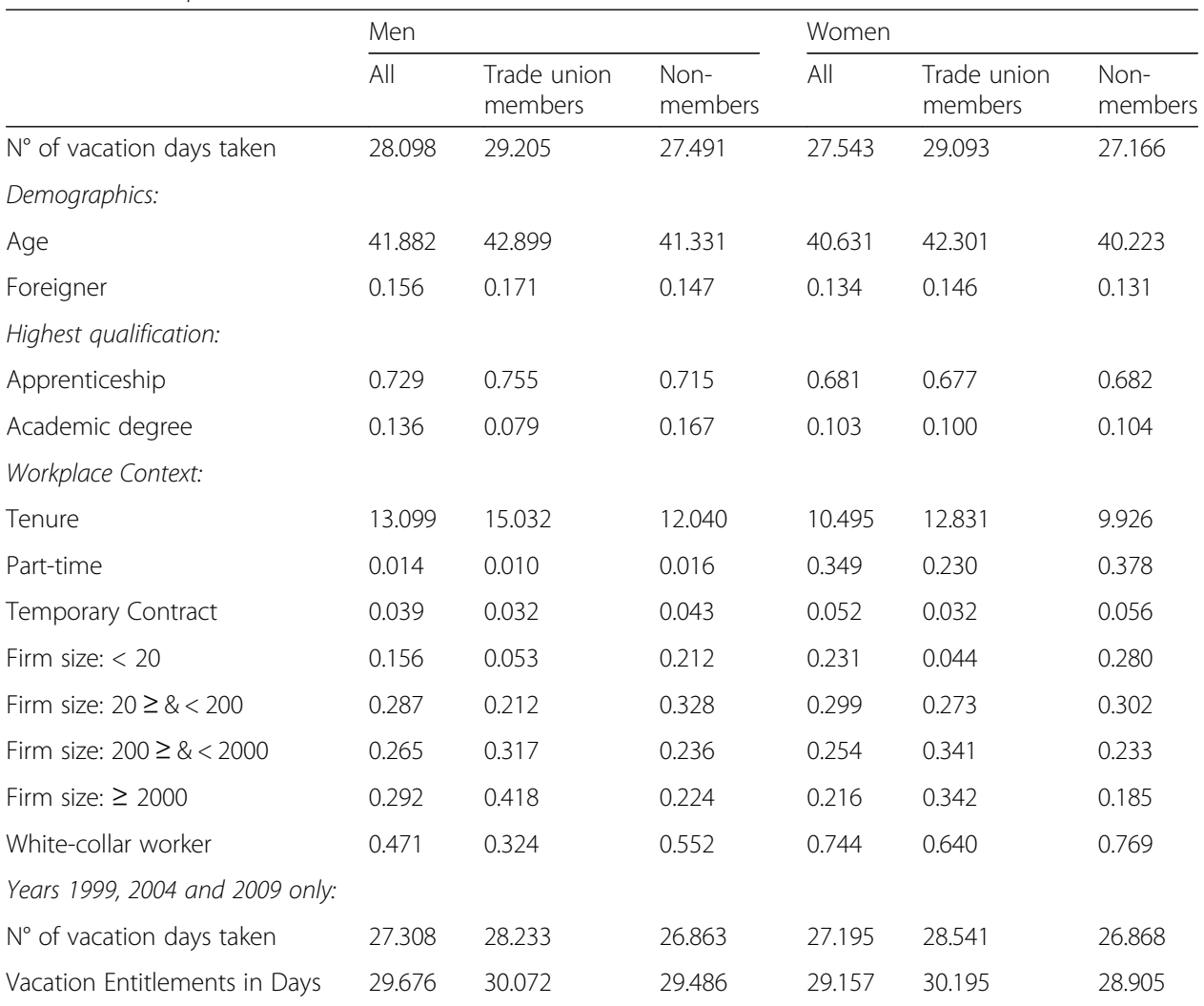

Note: SOEP 1985-2010. SOEP weights are used. Each multiply imputed data set $(m=60)$ is an unbalanced panel of the particular survey years with N_all: $31302\left(N_{-} \geq 1999: 13916\right)$

Table 1 shows that trade union members take approximately 29 vacation days per year, that is, about two days more than non-members, independently of the employees' gender. The data on vacation entitlements for the 3 years, for which this information is available, depicted in the lower part of Table 1, suggests that the difference in days of vacation taken may be partly due to higher entitlements for union members.

Additionally, members and non-members differ in other characteristics. Firstly, trade union members have higher tenure. Since other contributions suggest that vacation days rise with the time spent in a firm (cf. Green and Potepan 1988, Bryan 2006, Maume 2006, Fakih 2014), tenure might partially explain why members have more time off from work. Secondly, union members are more likely to work in larger firms. The studies by Green (1997), Ohtake (2003), Bryan (2006), and Maume (2006) indicate that the number of vacation days rises with firm size. Thus, the high rate of union members working in relatively large firms might be a further explanation for the raw difference in vacation days between members and non-members. Thirdly, the fraction of male non-members having a university degree is almost three times as large as that of their unionised counterparts. Moreover, there is some evidence that years of education and vacation are associated positively (Bryan 2006, Maume 2006, Fakih 2014). Therefore, the raw difference in days of vacation depicted in the first row of Table 1 may be less than the true membership impact on account of differential educational attainments.

Using regression analysis, we can control for the factors mentioned above and other observed differences in order to isolate the pure union membership vacation 
differential. The results from three pooled OLS specifications, in each case using all three imputation methods, are presented in Table 2. First, we use all the observations in our sample (specifications (1), (4) and (7)). Second, we estimate the model separately by gender because the relative weight of work and family might differ between men and women. Such differences could result in distinctions in vacation use, as suggested by Green and Potepan (1988) and Altonji and Usui (2007) for the United States, Bryan (2006) the United Kingdom, and Fakih (2014) for Canada.

The estimated parameters reported in Table 2 clarify that the number of vacation days rises with age and is higher for foreigners. Moreover, vacation days increase with tenure up to about 25 years of tenure (average effect of specifications (1), (4), and (7) in Table 2). Additionally, our results support previous findings that vacation days increase with firm size. Lastly, we obtain evidence suggesting that part-time workers, who are mostly female in Germany, take fewer vacation days.

Turning to the main variable of interest, the first row of Table 2 shows that the estimated coefficient of the union membership dummy is, on average, about 0.8 for men, almost unity for women, and about 0.9 for the entire sample. The union membership vacation differential is estimated consistently across imputation methods. This indicates the robustness of our results. The estimated coefficients translate into an increase of the days of vacation taken ranging from $2.8 \%$ of the total duration of vacation for males to $3.6 \%$ for female employees. This suggests that women may benefit more from union membership in terms of vacation days than men. However, adding an additional interaction term for being female and a member of a trade union to specifications (1), (4) and (7) does not affect the estimated parameter of the union membership dummy, while the estimated parameters of the interaction term are never significantly different from zero (results not documented). Therefore, the correlation between individual union membership and the number of vacation days does not vary with gender, in contrast to other countries (cf. Green and Potepan 1988, Bryan 2006, Altonji and Usui 2007 and Fakih 2014). Consequently, in the remainder of the paper, we focus on a pooled sample of men and women.

In Table 3, we report the findings from linear fixed-effects (FE) as well as correlatedrandom-effects (CRE_Poisson) specifications. We observe positive and significant effects of working in larger firms (with 200 employees or more) on vacation days of about half the magnitude as those obtained in pooled OLS specifications. The estimated tenure coefficients have the same signs and are in general significantly different from zero in correlated-random-effects (CRE_Poisson) specifications. Most importantly, the estimated coefficients of the union membership dummy in the FE specifications based on the second simple imputation method (SI 2) and on the multiply imputed data set (MI) are significantly different from zero at the 6 and 9\% level, respectively. They indicate that individual membership can raise the annual number of vacations days taken by about a third to at most $45 \%$ of a day. Using the same back-of-the envelope approach as employed in the introduction, the monetary equivalent of this effect is about one sixth to a quarter (0.35/0.44 days of vacation) of the annual membership fee of one per cent of gross income.

The average partial effect (APE) of trade union membership and its standard error in the CRE_Poisson specifications based on the second simple imputation method (SI 2) 
Table 2 Paid vacation and union membership in Germany (Pooled OLS)

\begin{tabular}{|c|c|c|c|c|c|c|c|c|c|}
\hline & (1) & $(2)$ & (3) & (4) & (5) & (6) & (7) & (8) & (9) \\
\hline & \multicolumn{3}{|c|}{ Simple Imputation 1 (SI 1) } & \multicolumn{3}{|c|}{ Simple Imputation 2 (SI 2) } & \multicolumn{3}{|c|}{ Multiple Imputation (MI) } \\
\hline & All & Men & Women & All & Men & Women & All & Men & Women \\
\hline \multirow[t]{2}{*}{ Union Membership $\left(u m_{i t}\right)$} & $0.900^{* * *}$ & $0.857^{* * *}$ & $0.944^{* * *}$ & $0.889^{* * *}$ & $0.752^{* * *}$ & $1.059^{* * *}$ & $0.881^{* * *}$ & $0.798^{* * *}$ & $0.965^{* * *}$ \\
\hline & $(0.192)$ & $(0.253)$ & $(0.269)$ & $(0.160)$ & $(0.208)$ & $(0.234)$ & $(0.202)$ & $(0.261)$ & $(0.314)$ \\
\hline \multirow[t]{2}{*}{ Age } & $0.054^{* * *}$ & $0.042^{* *}$ & $0.073^{* * *}$ & $0.050^{* * *}$ & $0.033^{* *}$ & $0.069^{* * *}$ & $0.042^{* * *}$ & $0.030^{* *}$ & $0.059^{* * *}$ \\
\hline & $(0.012)$ & $(0.017)$ & $(0.014)$ & $(0.010)$ & $(0.015)$ & $(0.013)$ & $(0.010)$ & $(0.015)$ & $(0.012)$ \\
\hline \multirow[t]{2}{*}{ Foreigner } & $0.854^{* * *}$ & $0.902^{* * *}$ & $0.886^{* *}$ & $0.994^{* * *}$ & $0.918^{* * *}$ & $1.187^{* *}$ & $0.880^{* * *}$ & $0.917^{* * *}$ & 0.885 \\
\hline & $(0.229)$ & $(0.257)$ & $(0.441)$ & $(0.256)$ & $(0.243)$ & $(0.579)$ & $(0.256)$ & $(0.241)$ & $(0.576)$ \\
\hline \multirow[t]{2}{*}{ Apprenticeship } & 0.147 & 0.195 & -0.124 & 0.105 & 0.164 & -0.164 & -0.016 & 0.169 & -0.420 \\
\hline & $(0.240)$ & $(0.304)$ & $(0.376)$ & $(0.212)$ & $(0.265)$ & $(0.334)$ & $(0.207)$ & $(0.257)$ & $(0.334)$ \\
\hline \multirow[t]{2}{*}{ Academic degree } & 0.598 & 0.517 & 0.483 & $0.588^{*}$ & 0.429 & 0.609 & 0.285 & 0.247 & 0.210 \\
\hline & $(0.372)$ & $(0.444)$ & $(0.483)$ & $(0.352)$ & $(0.415)$ & $(0.627)$ & $(0.335)$ & $(0.396)$ & $(0.585)$ \\
\hline \multirow[t]{2}{*}{ Tenure } & $0.105^{* * *}$ & $0.073^{* *}$ & $0.157^{* * *}$ & $0.102^{* * *}$ & $0.068^{* *}$ & $0.153^{* * *}$ & $0.111^{* * *}$ & $0.076^{* * *}$ & $0.163^{* * *}$ \\
\hline & $(0.026)$ & $(0.033)$ & $(0.042)$ & $(0.023)$ & $(0.030)$ & $(0.039)$ & $(0.023)$ & $(0.029)$ & $(0.039)$ \\
\hline \multirow[t]{2}{*}{ Tenure $^{2}$} & $-0.003^{* * *}$ & $-0.001^{*}$ & $-0.005^{* * *}$ & $-0.002^{* * *}$ & -0.001 & $-0.004^{* * *}$ & $-0.002^{* * *}$ & $-0.001^{*}$ & $-0.005^{* * *}$ \\
\hline & $(0.001)$ & $(0.001)$ & $(0.001)$ & $(0.001)$ & $(0.001)$ & $(0.001)$ & $(0.001)$ & $(0.001)$ & $(0.001)$ \\
\hline \multirow[t]{2}{*}{ Part-time } & $-0.527^{*}$ & -0.084 & $-0.671^{* *}$ & $-0.590^{* *}$ & -0.239 & $-0.723^{* * *}$ & $-0.669^{* * *}$ & -0.622 & $-0.782^{* * *}$ \\
\hline & $(0.278)$ & $(1.639)$ & $(0.272)$ & $(0.243)$ & $(1.284)$ & $(0.243)$ & $(0.240)$ & $(1.245)$ & $(0.242)$ \\
\hline \multirow[t]{2}{*}{ Temporary contract } & 0.151 & 0.641 & -0.370 & -0.064 & 0.262 & -0.429 & -0.097 & 0.304 & -0.532 \\
\hline & $(0.544)$ & $(0.955)$ & $(0.509)$ & $(0.464)$ & $(0.778)$ & $(0.445)$ & $(0.453)$ & $(0.763)$ & $(0.441)$ \\
\hline \multirow[t]{2}{*}{ Firm size: $20 \geq \&<200$} & $1.705^{* * *}$ & $0.939^{* * *}$ & $2.623^{* * *}$ & $1.671^{* * *}$ & $1.127^{* * *}$ & $2.393^{* * *}$ & $1.766^{* * *}$ & $1.303^{* * *}$ & $2.408^{* * *}$ \\
\hline & $(0.229)$ & $(0.320)$ & $(0.330)$ & $(0.204)$ & $(0.280)$ & $(0.298)$ & $(0.204)$ & $(0.282)$ & $(0.296)$ \\
\hline \multirow[t]{2}{*}{ Firm size: $200 \geq \&<2000$} & $2.787^{* * *}$ & $2.448^{* * *}$ & $3.041^{* * *}$ & $2.772^{* * *}$ & $2.711^{* * *}$ & $2.752^{* * *}$ & $2.857^{* * *}$ & $2.879^{* * *}$ & $2.768^{* * *}$ \\
\hline & $(0.250)$ & $(0.363)$ & $(0.348)$ & $(0.222)$ & $(0.316)$ & $(0.320)$ & $(0.224)$ & $(0.322)$ & $(0.319)$ \\
\hline
\end{tabular}


Table 2 Paid vacation and union membership in Germany (Pooled OLS) (Continued)

\begin{tabular}{|c|c|c|c|c|c|c|c|c|c|}
\hline \multirow[t]{2}{*}{ Firm size: $\geq 2000$} & $3.289^{* * *}$ & $2.893^{* * *}$ & $3.601^{* * *}$ & $3.228^{* * *}$ & $3.146^{* * *}$ & $3.240^{* * *}$ & $3.393^{* * *}$ & $3.414^{* * *}$ & $3.270^{* * *}$ \\
\hline & $(0.236)$ & $(0.326)$ & $(0.353)$ & $(0.215)$ & $(0.292)$ & $(0.335)$ & $(0.222)$ & $(0.306)$ & $(0.344)$ \\
\hline \multirow[t]{3}{*}{ White-collar Worker } & 0.040 & -0.147 & $0.645^{*}$ & 0.016 & -0.177 & $0.580^{* *}$ & 0.026 & -0.171 & $0.592^{* *}$ \\
\hline & $(0.193)$ & $(0.221)$ & $(0.330)$ & & & & $(0.169)$ & $(0.199)$ & $(0.294)$ \\
\hline & & & & $(0.168)$ & $(0.197)$ & $(0.292)$ & & & \\
\hline \multirow[t]{2}{*}{ Unemployment Rate } & -0.013 & $-0.076^{* *}$ & $0.068^{* *}$ & -0.015 & $-0.069^{* *}$ & $0.053^{*}$ & $-0.062^{* * *}$ & $-0.116^{* * *}$ & 0.007 \\
\hline & $(0.025)$ & $(0.036)$ & $(0.032)$ & $(0.021)$ & $(0.030)$ & $(0.028)$ & $(0.018)$ & $(0.025)$ & $(0.027)$ \\
\hline \multirow[t]{2}{*}{ Female } & -0.122 & & & -0.040 & & & -0.027 & & \\
\hline & $(0.190)$ & & & $(0.174)$ & & & $(0.172)$ & & \\
\hline \multirow[t]{2}{*}{ Constant } & $22.771^{* * *}$ & $24.126^{* * *}$ & $20.889^{* * *}$ & $22.882^{* * *}$ & $24.059^{* * *}$ & $21.294^{* * *}$ & $22.910^{* * *}$ & $23.943^{* * *}$ & $21.558^{* * *}$ \\
\hline & $(0.511)$ & $(0.644)$ & $(0.852)$ & $(0.480)$ & $(0.591)$ & $(0.813)$ & $(0.468)$ & $(0.578)$ & $(0.755)$ \\
\hline N & 26394 & 15559 & 10835 & 30359 & 18056 & 12303 & 31302 & 18578 & 12724 \\
\hline NI (number of imputed values) & 19556 & 11284 & 8272 & 23521 & 13781 & 9740 & 24464 & 14303 & 10161 \\
\hline n (number of individuals) & 11670 & 6465 & 5205 & 12909 & 7173 & 5736 & 13179 & 7317 & 5862 \\
\hline Wald_x (df) & $926.9^{* * *}(31)$ & $629.1^{* * *}(30)$ & $366.9^{* * *}(30)$ & $1016.8^{* * *}(31)$ & $729.9 * * *(30)$ & $357.9^{* * *}(30)$ & $892.9^{* * *}(23)$ & $608.3 * * *(22)$ & $323.8^{* * *}(22)$ \\
\hline
\end{tabular}

Note: SOEP 1985-2010. MI: Each imputed data set $(\mathrm{m}=60)$ is an unbalanced panel of the particular survey years with $\mathrm{N} \_$all: 31302

Dependent variable: Number of paid vacation days taken per year. Standard errors in parentheses, ${ }^{*} p<0.10,{ }^{* *} p<0.05,{ }^{* * *} p<0.01$

Wald_x (df): Wald-test with HO: no joint significance of all covariates. Additionally controlled for industries (NACE 1-digit) \& survey year. SOEP weights are used 
Table 3 Paid vacation and union membership in Germany (Panel Data Models)

\begin{tabular}{|c|c|c|c|c|c|c|}
\hline & \multicolumn{3}{|l|}{ Linear Fixed-Effects (FE) } & \multicolumn{3}{|c|}{ Correlated-Random-Effects Poisson (CRE_Poisson) (APEs) } \\
\hline & $(1)$ & (2) & (3) & (4) & (5) & (6) \\
\hline & Simple Imputation 1 (SI 1) & Simple Imputation 2 (SI 2) & Multiple Imputation (MI) & Simple Imputation 1 (SI 1) & Simple Imputation 2 (SI 2) & Multiple Imputation (MI) \\
\hline Union Membership (umit) & $0.224(0.370)$ & $0.441^{*}(0.232)$ & $0.349 *(0.204)$ & $0.188(0.352)$ & $0.421 *(0.226)$ & $0.357(0.224)$ \\
\hline Mean Union Membership $\left(\overline{u m}_{i}\right)$ & -- & -- & -- & $0.596(0.421)$ & $0.486(0.309)$ & $0.511^{*}(0.304)$ \\
\hline Tenure & $0.012(0.033)$ & $0.012(0.030)$ & $0.029(0.028)$ & $0.064^{* * *}(0.024)$ & $0.065^{* * *}(0.023)$ & $0.020(0.024)$ \\
\hline Tenure $^{2}$ & $-0.001(0.001)$ & $-0.001(0.001)$ & $-0.001(0.001)$ & $-0.001^{* *}(0.001)$ & $-0.002^{* *}(0.001)$ & $-0.002^{* * *}(0.001)$ \\
\hline Part-time & $-0.647(0.400)$ & $-0.672^{*}(0.352)$ & $-0.636^{*}(0.350)$ & $-0.567^{* *}(0.283)$ & $-0.477^{*}(0.254)$ & $-0.537^{* *}(0.249)$ \\
\hline Temporary contract & $-0.049(0.521)$ & $-0.177(0.449)$ & $-0.148(0.447)$ & $0.200(0.461)$ & $-0.049(0.394)$ & $0.067(0.376)$ \\
\hline Firm size: $20 \geq \&<200$ & $0.376(0.361)$ & $0.397(0.317)$ & $0.384(0.313)$ & $0.553(0.363)$ & $0.628^{*}(0.332)$ & $0.535(0.335)$ \\
\hline Firm size: $200 \geq \&<2000$ & $1.564^{* * *}(0.454)$ & $1.528^{* * *}(0.388)$ & $1.463^{* * *}(0.387)$ & $1.793^{* * *}(0.440)$ & $1.714^{* * *}(0.390)$ & $1.575^{* * *}(0.390)$ \\
\hline Firm size: $\geq 2000$ & $1.549^{* * *}(0.431)$ & $1.699^{* * *}(0.377)$ & $1.690^{* * *}(0.383)$ & $1.768^{* * *}(0.431)$ & $2.004^{* * *}(0.393)$ & $1.894^{* * *}(0.398)$ \\
\hline Unemployment rate & $0.094(0.064)$ & $0.078(0.059)$ & $-0.075^{*}(0.041)$ & $-0.005(0.024)$ & $-0.006(0.022)$ & $-0.064^{* *}(0.020)$ \\
\hline N & 21028 & 24938 & 25776 & 21028 & 24938 & 25776 \\
\hline NI (number of imputed values) & 14928 & 18031 & 19697 & 14928 & 18031 & 19697 \\
\hline n (number of individuals) & 6226 & 7384 & 7653 & 6226 & 7384 & 7653 \\
\hline Wald_x (df) & $60.4^{* * *}(25)$ & $75.26^{* * *}(25)$ & $45.9^{* * *}(17)$ & $601.6^{* * *}(32)$ & $690.5^{* * *}(32)$ & $600.88^{* * *}(27)$ \\
\hline
\end{tabular}

Note: SOEP 1985-2010. Ml: Each imputed data set $(m=60)$ is an unbalanced panel of the particular survey years with $N \_$all: 31302

Dependent variable: Number of paid vacation days taken per year. Standard errors in parentheses, ${ }^{*} p<0.10,{ }^{* *} p<0.05,{ }^{* * *} p<0.01$

Additionally controlled for industries (NACE 1-digit) \& survey year. SOEP weights are used

Wald $\mathrm{x}$ (df): Wald-test with $\mathrm{HO}$ : no joint significance of all covariates 
and the multiply imputed data set (MI) are very similar in size to the FE-estimates, though marginally insignificant in the MI case. Moreover, we find comparable estimated APEs of the individual-specific mean of trade union membership in both above-mentioned cases, once again marginally insignificant for one imputation approach (SI 2). The estimated APEs indicate that more than $50 \%$ of the pooled OLS union-membership vacation premium of one day is due to selection into union membership. Reassuringly, in all CRE_Poisson specifications the two estimated APEs of union membership broadly add up to the size of the pooled OLS union membership vacation differential of 0.9 days.

In sum, the various linear fixed-effects and CRE_Poisson specifications are compatible with an interpretation according to which individual union membership can cause annual vacation days to rise by at most half a day. The larger part of the pooled OLS-vacation differential, however, is due to selection effects.

\section{Robustness checks}

In this section, we look at two issues: First, does the imputation of individual trade union membership affect results? Second, are our findings limited to or primarily determined by the behaviour of particular employees? ${ }^{12}$

\subsection{Complete case analyses}

The results presented in Section 4 rely on different strategies to impute the individual union membership status for all those years for which vacation data is available, but no information with respect to membership is contained in the SOEP questionnaire. Tables 2 and 3 demonstrate that the findings are qualitatively unaffected by the type of imputation method applied - SI 1, SI 2, or MI. To further gauge the robustness of our findings with regard to the imputation strategy as such, we restrict our sample to years for which information on both of our main variables exists. First, we estimate specifications (1) and (2) for the years 1985 and 1989 only, for which we have complete contemporaneous information about individual trade union membership and vacation days (complete case (CC); see Table 5 in the Appendix). Second, we combine information on union membership in a given year $t$ with data on vacation days in the subsequent year $t+1$. The resulting sample is based on information for the pairs of years $1985 / 6$, 1998/9 and 2003/4 (see Table 5 in the Appendix) and denoted as quasi-complete case (QCC). The advantage of the QCC-setting, relative to the complete case analysis (CC), is that the sample size increases substantially, since we can use more recent information additionally, and that union membership is predetermined with regard to the observed choice of vacation days.

The estimated coefficients of the union membership variable for the pooled OLS specifications depicted in Table 4 are broadly similar to those shown in Table 2. In particular, we continue to observe a sizeable union membership vacation differential. When we exploit the panel dimension of the data, we can again discern a significant but notably lower effect of union membership on paid vacation, but only for the estimations based on the quasi-complete case setting (QCC). All in all, the findings presented in Section 4 can, hence, be regarded as robust with respect to the imputation of union membership information. ${ }^{13}$ 
Table 4 Paid vacation and union membership (Complete Case Analyses)

\begin{tabular}{|c|c|c|c|c|c|c|}
\hline & \multicolumn{2}{|l|}{ Pooled OLS } & \multicolumn{2}{|c|}{ Linear Fixed-Effects (FE) } & \multicolumn{2}{|c|}{ Correlated-Random Effects Poisson (CRE_Poisson) (APEs) } \\
\hline & $\mathrm{CC}$ & QCC & $\overline{C C}$ & QCC & $\mathrm{CC}$ & QCC \\
\hline Union Membership $\left(u m_{i t}\right)$ & $0.731^{* * *}(0.246)$ & $1.021^{* * *}(0.188)$ & $0.261(0.677)$ & $0.887^{* *}(0.416)$ & $0.22(0.662)$ & $0.667^{*}(0.392)$ \\
\hline Mean Union Membership $\left(\overline{u m}_{i}\right)$ & -- & -- & -- & -- & $0.47(0.63)$ & $0.062(0.468)$ \\
\hline Wald_x (df) & $371.0 * *(24)$ & $608.1^{* * *}(26)$ & $21.37(18)$ & $45.34^{* * *}(20)$ & $181.21^{* * *}(24)$ & $230.89^{* * *}(28)$ \\
\hline N & 6838 & 13575 & 4262 & 6145 & 4262 & 6145 \\
\hline$n$ (number of individuals) & 4717 & 10291 & 2131 & 2832 & 2131 & 2832 \\
\hline
\end{tabular}

Note: SOEP. CC: Complete case analysis, based on information for the years 1985, 1989

QCC: Quasi-complete case analysis, based on information for the pairs of years 1985/6, 1998/9, 2003/4

Dependent variable: Number of paid vacation days taken per year

Standard errors in parentheses, ${ }^{*} p<0.10,{ }^{* *} p<0.05,{ }^{* * *} p<0.01$

Additional covariates: see Tables 2 and 3. SOEP weights are used

Wald_x (df): Wald-test with H0: no joint significance of all covariates 


\subsection{Subgroups}

In order to investigate whether our results are affected by particular legal regulations or employer as well as employee characteristics, we re-estimated our specifications for various subsamples. Subsequently, we summarise the findings relating to the variables of main interest, focussing on the imputed data sets. ${ }^{14}$

First, we look at employees who are very likely to be covered by collective bargaining and to work in plants in which a works council exists. The idea is to make our estimates contingent on work places in which collective bargaining determines vacation entitlements and works councils represent the interests of employees. In particular, we focus on a subsample of people who work in firms with at least 2,000 employees. In this subgroup, collective bargaining coverage has always been high and still exceeds 90\%. Moreover, according to Ellguth and Kohaut (2013), who analyse data by Institute for Employment Research, 88\% (95\%) of the employees working in establishments with more than 500 employees were represented by a works council in 2012 (1998). Additionally, own calculations on the basis of SOEP data for the years 2001, 2006 and 2011 indicate that the coverage by works councils was about $90 \%$ in plants with more than 2,000 employees. Finally, bargaining and works council coverage have hardly changed in large plants over the last decades.

We observe significant estimated coefficients of the union membership dummies in the pooled OLS specifications of the same magnitude for the sample of individuals who work in large firms, as for the entire sample (cf. Table 2). This indicates that the union membership vacation premium is not predominantly driven by selection into work places with collective bargaining and works council coverage. However, we find no evidence of an individual union membership effect in the two panel-data specifications and higher estimated coefficients of individual averaged union membership in the CRE_Poisson specifications, relative to the full sample (cf. Table 3). These results suggest that selection into union membership may be even more important in larger than in smaller firms with regard to paid vacation use.

Second, we focus on a sample of employees for whom we have information about vacation entitlements. By doing so, we can tackle the question of whether trade union members take more days of paid vacation, simply because they are entitled to longer vacations, in line with the anecdotal evidence reported in the introduction. Because information on vacation entitlements is only available for three waves in more recent years (see Table 5 in the Appendix), we cannot apply the multiple imputation procedure which is based on complete case information for 1985 and 1989. We subsequently report the findings of estimating equation (1) by pooled OLS, adding the vacation entitlement as an additional covariate, since exploiting the panel dimension of the data yields no significant results. The union membership vacation premium shrinks by more than $50 \%$ relative to the full sample, while the estimated coefficients of vacation entitlement are significantly positive with a magnitude of 0.86 . This suggests that in Germany employees, on average, do not fully exploit their vacation entitlements (see also Saborowski 2005 and Schnitzlein 2012). Therefore, the pooled OLS-union membership vacation differential is mitigated if entitlements are accounted for, but cannot be entirely due to selection into high-entitlement jobs or firms.

Third, we restrict our sample to those employees who do not change their employer. Using this more selective sample of firm stayers, the estimated OLS-coefficients 
indicate a significant union membership vacation differential of about 0.8 days. Additionally, when we apply the FE-estimator, we find a parameter estimate of 0.376 based on the multiple imputation strategy, which resembles the results from the main sample but is not significant at conventional levels $(\alpha=0.152)$. Moreover, the estimated parameter of individual averaged union membership in the CRE_Poisson specification is significantly different from zero and again indicates that selection into union membership is important. Since the FE-estimator is based on a sample of firm stayers and, hence, implicitly controls for firm-fixed effects, time-invariant personnel policies do not seem to have an important effect on the observed union membership vacation differential.

Fourth, we look at the main segments of the economy. More precisely, we estimate our specifications separately for the private and the public sector and differentiate between the industrial and the service sector. The rationale for the first distinction is the argument that unions in the public sector may not be comparable to private sector unions as, for example, evidenced by differential union density and collective bargaining coverage rates. Therefore, the impact of individual union membership on vacation use may also vary. The second distinction is motivated by the fact that trade unions and works councils have traditionally played a more important role in industry than in services.

When we restrict our sample to respondents who work in the private sector, the estimated union membership coefficients are comparable to those obtained for the full sample depicted in Tables 2 and 3, with the exception of the FE and CRE_Poisson specifications based on the second simple imputation strategy (SI 2). Furthermore, we do not observe a systematic relationship between vacation days and union membership for public sector workers. With regard to the second distinction, separate estimations for industry and services yield significant pooled OLS-estimates of the union membership dummy which are about twice as large in magnitude in services as in the industrial sector. Additionally, the FE specification for the service sector using the sample based on the second simple imputation approach (SI 2) yields a significant coefficient of individual union membership which is about twice the magnitude of that detected for the full sample (cf. Table 3, specification (2)). Finally, the estimated coefficients of individual averaged union membership in the CRE_Poisson specifications for the industrial sector are significantly different from zero for the simple imputation approaches (SI 1, SI 2), while this is not the case with respect to services. Accordingly, our evidence suggests that the union membership vacation premium might vary across sectors and that it is predominantly a private sector phenomenon.

Finally, we investigate whether the union membership vacation differential varies with work experience. In order to do so, we separately estimate specifications for subgroups of individuals with less than 10 years of full-time experience, between 10 and 22, and more than 22 years. ${ }^{15}$ The idea underlying these subgroup analyses is that experience and union membership are substitutes with respect to information about how to utilise vacation entitlements. Furthermore, more experienced workers may be better protected against dismissals and face less severe career consequences when taking vacation. Consequently, union membership can be expected to have more of an impact on vacation use for less experienced workers.

The estimated coefficients of the union membership dummy become substantially larger for the group of less-experienced workers than those depicted in Tables 2 and 3 
for the full sample, while the coefficients for the respondents with the highest experience are smaller and estimated less precisely. Therefore, these results are compatible with the idea that unions provide members with goods or services which individuals can only acquire after a lengthy period of work, such as information or the possibility to make complete use of legal entitlements. However, some care has to be taken when putting forward this interpretation, given that union members are on average older, have higher tenure, work more often full-time and are, therefore, more experienced than non-members (see Table 1).

Taken together, our results for various subgroups confirm the existence of a union membership vacation differential and underline the great importance of selection into membership as an explanation. The magnitude of the vacation differential varies across subgroups, but it still exists if vacation entitlements are taken into account as an additional covariate, when bargaining and works council coverage and time-invariant firm characteristics are indirectly accounted for, and it is particularly large in services.

\section{Conclusions}

Reductions in working time have been a longstanding objective of trade unions. While the focus has been on weekly working hours, an extension of annual paid vacations has also been a prominent issue in many European countries. A relationship between the strength of trade unions and vacations can arise, at least, via two channels. Trade unions may negotiate higher vacation entitlements, such that all employees covered by collective bargaining agreements will benefit. Second, trade union membership may enable employees to take extra vacation days. Given the industrial relations setting in Germany, where collective contracts are generally applied to all employees in a firm irrespective of whether they belong to a trade union or not, we focus on the second channel and enquire whether an individual's union membership status affects the duration of vacation.

Our pooled OLS-estimates indicate that trade union members have almost one day more paid vacation than non-members annually, controlling for a host of demographic and workplace-related variables. Taken at face value, the monetary equivalent of this union membership vacation premium is $0.5 \%$ of annual gross income. It covers about $50 \%$ of the union membership fee in Germany and thereby points to a remarkable private gain from individual trade union membership. However, this effect is substantially smaller in magnitude than the union membership vacation differential estimated in various studies for the United States of about 3 to 5 days (Green and Potepan 1988, Buchmueller et al. 2004, Maume 2006, Altonji and Usui 2007). When we exploit the panel data dimension of our data set and estimate linear fixed-effects and nonlinear correlated-random-effects specifications, the estimated coefficient of the union membership dummy is no longer significant at conventional standards in our preferred specifications based on the imputed data sets, but only at the $10 \%$-level in two out of three cases. Moreover, the magnitude of the union membership vacation premium shrinks to around 0.4 days. Hence, the larger part of the OLS-union membership vacation premium seems to be driven by self-selection into union membership. This interpretation is supported by evidence from various subgroup-specific analyses.

These results are of great relevance from an industrial relations perspective because they indicate a dilemma for trade unions: The upper limit for a possible gain in vacation due to union membership, as indicated by the FE-estimates, is relatively small 
and would presumably not induce employees to join a union exclusively based on pecuniary motives. However, a union membership vacation premium of an extra day of vacation, irrespective of whether this is a true membership or a selection effect, indicates that the effective labour costs of union members will be higher than those of non-members by about $0.5 \%$, and this might have a detrimental effect on their (re-) employment probabilities.

Our findings also indicate areas for future research. First, the results for various subgroups indicate that the estimated average union membership vacation differential might vary notably across sectors and industries. In particular, it seems that individual union membership may enhance vacations to a greater extent in sectors in which trade unions have usually been weaker, such as in services. Additionally, we do not observe a union vacation differential in the public sector which has traditionally been a stronghold of trade unions. If the vacation effect is particularly pronounced in work environments where trade unions are relatively weak, this might indicate a remarkable private gain for some union members. Unfortunately, our data does not allow us to look into the potential heterogeneity of the union membership vacation differential in more detail. Second, based on the information from the German Socio-Economic Panel, we can only speculate why individual union membership enables employees to take more vacation. Better information of members about entitlements might explain part of it, but we still observe a union membership vacation differential contingent on vacation entitlements and for respondents with substantial periods of work experience. Better protection against dismissals (e.g. Goerke and Pannenberg 2011) might also add to the explanation of the vacation differential.

\section{Endnotes}

${ }^{1}$ See Schnitzlein (2012) for Germany, Altonji and Usui (2007) for the United States, and Bryan (2006) for the United Kingdom.

${ }^{2}$ Note that Fakih (2014) combines information on coverage and individual union membership, whereas Shi and Skuterud (2015) present evidence with respect to the probability of being absent in a reference week due to vacation. Freeman (1981) furthermore shows that the costs of vacation pay in the United States are higher if there is collective bargaining.

${ }^{3}$ According numbers are provided by Visser (2013) with respect to bargaining (or union) coverage, labelled adjusted coverage (AdjCov) and union density (UD_s), respectively.

${ }^{4}$ See the article in the newspaper Süddeutsche Zeitung (in German) (http:// www.sueddeutsche.de/karriere/mitarbeiter-erster-klasse-1.947983; January 30, 2014). In the United Kingdom, the University and College Union, for example, states that "union members ...receive ... more holiday ... than non-members." (UCU factsheet 01; http:// www.ucu.org.uk/media/pdf/2/d/UCU_factsheet1_unions.pdf; February 27, 2014).

${ }^{5}$ According to a representative survey conducted on behalf of the public sector union ver.di, almost $20 \%$ of respondents did not know that there is a legal minimum vacation entitlement in Germany, more than $25 \%$ were not aware of its magnitude and a quarter of those asked were unacquainted with the fact that the employer could not unilaterally determine the date of vacations. Furthermore, the campaign (in German) by ver.di relating to the trade unions' success in contractually establishing and extending 
vacation entitlements in Germany beyond the legal minimum emphasises the role of the union in enforcing such claims (http://www.verdi.de/themen/arbeit/aktionswoche-urlaub-2013; January 30, 2014).

${ }^{6}$ Wagner et al. (2007) provide more detailed information on the SOEP data. See also: http://www.diw.de/english/soep/29012.html.

${ }^{7}$ Own translation. Until 1990, the question had a small supplement, asking for being employed in the previous year: "If you were employed in 19xx: How many days of vacation did you take last year?". Thereafter, the structure of the survey changed so that this supplement was not necessary anymore. Furthermore, in the three most recent waves the question explicitly referred to working days.

${ }^{8}$ This date of change is determined as $(t+x) / 2$ if $t+x$ is even or as $(t+x+1) / 2$ if $t+x$ is an odd number, with $t$ and $x, t<x$, denoting the years of two adjacent waves in which union membership information is available. We also implemented two further simple imputation strategies. If membership information changes from year $t$ to year $x$, we assume (i) that the membership status alters at the beginning of the period of incomplete information, that is in $t+1$, or (ii) at the end of the relevant interval (that is in $x$ ). The results obtained when using these alternative imputation strategies are not reported since they are comparable.

${ }^{9}$ See Seaman et al. (2012) and White et al. (2010) for details with respect to the multiple imputation procedure. We outline our approach in more detail in the Appendix.

${ }^{10}$ The relevant question is "How many vacation days can you take according to your contract?". Saborowski (2005) and Schnitzlein (2012) use this question and the one relating to days actually taken to analyse the determinants of the difference between vacation entitlement and vacation use.

${ }^{11}$ See http://www.dgb.de/uber-uns/dgb-heute/mitgliederzahlen/2010. In line with our data, Visser (2013) reports an average union density for Germany for the period 1985 to 2010 of $27 \%$.

${ }^{12} \mathrm{~A}$ documentation of the entire set of results reported in this section is available upon request.

${ }^{13}$ Applying the generalised missing-indicator approach suggested by Dardanoni et al. (2011) we, furthermore, checked for potential bias induced by improper imputations. We do not find evidence for such a bias under reasonable assumptions, e.g. the estimated union membership vacation premium is 0.87 using weighted-average least squares estimators in the pooled data case. We are grateful to an anonymous referee for suggesting the use of the observed missing data patterns in our analysis.

${ }^{14}$ Subsample analyses for CC- and QCC-settings are not informative, given the small number of observations.

${ }^{15} \mathrm{We}$ are grateful to an anonymous referee for the valuable suggestion of pursuing this subgroup analysis. Note that the cut-off points for the definition of experience guarantee samples of roughly the same size. However, findings are not sensitive to the exact specification. Similar results as reported below with respect to SI 1 and SI 2; working samples are obtained if we add interactions terms to specification (1) and estimate it for the entire sample.

${ }^{16}$ Note, that we do not use a conventional deterministic imputation framework where we should not include the dependent variable of the analysis model of interest, since it would lead to biased estimates. In the MI framework, the introduced random component avoids this bias. 


\section{Appendix: Trade Union Membership and Paid Vacation in Germany} Temporal Structure of Data and Number of Imputations

Table 5 Information on Vacation and Union Membership in SOEP

\begin{tabular}{|c|c|c|c|c|c|c|c|c|c|c|c|}
\hline & 1984 & 1985 & 1986 & 1987 & 1988 & 1989 & 1990 & 1993 & 1994 & & \\
\hline $\begin{array}{l}\text { Union } \\
\text { Membership }\end{array}$ & & OCC & & & & & & & & & \\
\hline \multirow[t]{2}{*}{$\begin{array}{l}\text { Vacation } \\
\text { Days }\end{array}$} & & & OCC & & & & & & & & \\
\hline & 1998 & 1999 & 2001 & 2002 & 2003 & 2004 & 2007 & 2008 & 2009 & 2011 & 2012 \\
\hline $\begin{array}{l}\text { Union } \\
\text { Membership }\end{array}$ & $\overline{Q C C}$ & & & & $\overline{\mathrm{QCC}}$ & & & & & & \\
\hline $\begin{array}{l}\text { Vacation } \\
\text { Days }\end{array}$ & & QCC & & & & QCC & & & & & \\
\hline $\begin{array}{l}\text { Vacation } \\
\text { Entitlement }\end{array}$ & & & & & & & & & & & \\
\hline
\end{tabular}

Note:

Intermittent years, such as 1991, are omitted for notational convenience because the SOEP questionnaires do not contain relevant information in those years. For information with respect to the exact timing of questions, see the main text Cells marked in green $(\square)$ indicate that responses are available for the relevant year

Years marked in red $(\square)$ indicate the years that are used for the complete case analysis (CC)

Cells marked in blue $(\square)$ indicate that responses are used for the quasi-complete case analysis (QCC)

Table 6 Number of observations and of imputed union membership

\begin{tabular}{|c|c|c|c|c|c|c|c|c|}
\hline & 1985 & 1986 & 1987 & 1988 & 1989 & 1999 & 2004 & 2009 \\
\hline Vacation days & 3509 & 3275 & 3018 & 2945 & 3329 & 4169 & 6131 & 4926 \\
\hline \multicolumn{9}{|c|}{ Union membership } \\
\hline SI 1 & & 2469 & 2419 & 2522 & & 3470 & 4742 & 3934 \\
\hline SI 2 & no imputation & 3275 & 2807 & 2945 & no imputation & 4151 & 6096 & 4247 \\
\hline Ml & & 3275 & 3018 & 2945 & & 4169 & 6131 & 4926 \\
\hline
\end{tabular}

\section{Note:}

Row 1 depicts the number of observations with information on vacation and all covariates. Rows 3 to 5 show the number of observations for which union membership status is imputed according to the different imputation strategies in those years for which the SOEP does not provide this information directly 


\section{Description of Multiple Imputation (MI) procedure}

Our SOEP working panel data set provides us with complete information with regard to days of paid vacation taken and union membership for 1985 and 1989 only. For the other years, for which information on paid vacation days taken is available (1986, 1987, 1988, 1999, 2004, 2009), we do not have contemporaneous information on union membership. However, in this case, union membership information is available for adjacent years $(1985,1989,1993,1998,2001,2003,2007,2011)$. Therefore, we use Multiple Imputation (MI) to impute the missing union membership information. $\mathrm{MI}$ is a simulation-based approach for analysing incomplete data (see e.g. Rubin 1987, White et al. 2010 and Cameron/Trivedi 2005). Our MI procedure replaces missing values of union membership with multiple sets of simulated values to complete the data, applies standard regression techniques (OLS; FE; CRE_Poisson) to analyse each completed data set and adjusts the obtained parameter estimates for missing-data uncertainty by means of Rubin's Rules.

We use the Stata suite MI (Stata Version 12; StataCorp LP 2011) to perform the MI exercises. In particular, we use binary logit specifications of a union membership equation in our imputation model based on the complete data set for the years 1985 and 1989. Most importantly, we exploit the longitudinal structure of our data set at hand and include a dummy variable indicating individual union membership status in any other year (umother) as a covariate. Other covariates of our regression models of interest (equations 1 and 2 in the main part of the paper) are also included as well as the dependent variable of these regression models "days of paid vacation taken" (fvacreal). The reason for including the dependent variable of the regression models into the imputation model is that otherwise the missing union membership would be imputed as though it had no relationship with paid vacation taken. This would bias the estimated parameter of union membership in our regression models of interest towards zero (e.g. Allison 2002 or White et al. 2010). ${ }^{16}$ Moreover, we include the following auxiliary variables: party preferences (SPD, CDU/CSU, GRUENE), intensity of party preferences (partystrong) as well as four dummies indicating whether the individual observation exhibits a survey weight which is located in different quintiles of the distribution of survey weights in the particular year $(q *$ weight $)$. We separately impute the missing union membership information for males and females applying Stata MI's "by" option. This allows the association between paid vacation and union membership to differ between males and females. Hence, we can include interactions of gender and union membership in our regression models of interest without bias (e.g. White et al. 2010) and test whether the union membership vacation differential varies with gender. The number of imputations is $\mathrm{m}=60$.

The Stata-listings on the next pages display the results of an example of our MI procedure.

Further References

Allison PD. (2002), Missing Data, Sage Publications.

Cameron CA and Trivedi PK (2005), Microeconometrics. Methods and Applications, Cambridge University Press.

Rubin DB (1987), Multiple Imputation for Nonresponse in Surveys, John Wiley.

StataCorp LP (2011), STATA MULTIPLE IMPUTATION REFERENCE MANUAL, RELEASE 12. 


\section{Logit estimates union membership equation for subgroup of females}

\begin{tabular}{|c|c|c|c|c|c|c|}
\hline \multirow{2}{*}{\multicolumn{3}{|c|}{ Logistic regression }} & \multicolumn{2}{|c|}{ Number of obs } & \multicolumn{2}{|c|}{2563} \\
\hline & & & \multirow{2}{*}{\multicolumn{2}{|c|}{$\begin{array}{l}\text { LR chi2 }(30) \\
\text { Prob > chi2 }\end{array}$}} & 105 & 1055.35 \\
\hline & & & & & \multicolumn{2}{|c|}{0.0000} \\
\hline \multicolumn{3}{|c|}{ Log likelihood $=-786.63716$} & \multicolumn{2}{|c|}{ Pseudo R2 } & 0. & 4015 \\
\hline union | & Coef. & Std. Err. & z & $P>|z|$ & [95\% Conf. & Interval] \\
\hline fvacreal | & .0182872 & .0085081 & 2.15 & 0.032 & .0016117 & .0349627 \\
\hline umother | & 3.905439 & .2024242 & 19.29 & 0.000 & 3.508695 & 4.302183 \\
\hline foreign | & .0652863 & .2951885 & 0.22 & 0.825 & -.5132726 & .6438451 \\
\hline tenure | & -.0061831 & .0264968 & -0.23 & 0.815 & -.058116 & .0457497 \\
\hline tensqu I & .0006856 & .0008625 & 0.79 & 0.427 & -.0010049 & .0023762 \\
\hline whitecollar | & -.8799385 & .1867439 & -4.71 & 0.000 & -1.24595 & -.5139271 \\
\hline berufsabschluss | & .4142952 & .1696006 & 2.44 & 0.015 & .0818841 & .7467063 \\
\hline hochschulabschluss | & .283355 & .3757424 & 0.75 & 0.451 & -.4530865 & 1.019797 \\
\hline teilzeit | & -.6414053 & .1748072 & -3.67 & 0.000 & -.984021 & -.2987896 \\
\hline tempconnew | & -.4155986 & .3292712 & -1.26 & 0.207 & -1.060958 & .2297612 \\
\hline gr199 | & 1.486059 & .2991599 & 4.97 & 0.000 & .8997158 & 2.072401 \\
\hline $\operatorname{gr1999} \mid$ & 1.940324 & .2985828 & 6.50 & 0.000 & 1.355113 & 2.525536 \\
\hline gr2000 । & 2.135088 & .3039367 & 7.02 & 0.000 & 1.539383 & 2.730792 \\
\hline unemploymentrate | & .0839654 & .0282195 & 2.98 & 0.003 & .0286561 & .1392747 \\
\hline minen | & -.7928851 & 1.178543 & -0.67 & 0.501 & -3.102787 & 1.517017 \\
\hline manufacturing | & .6757443 & .3098372 & 2.18 & 0.029 & .0684745 & 1.283014 \\
\hline construction | & .6341264 & .3660237 & 1.73 & 0.083 & -.0832668 & 1.35152 \\
\hline trade I & .5207435 & .3465009 & 1.50 & 0.133 & -.1583858 & 1.199873 \\
\hline transport | & 1.547478 & .5051057 & 3.06 & 0.002 & .5574887 & 2.537467 \\
\hline bank I & -.1401736 & .4479957 & -0.31 & 0.754 & -1.018229 & .7378818 \\
\hline services | & .0047399 & .3183472 & 0.01 & 0.988 & -.6192092 & .6286889 \\
\hline y89 । & .0070343 & .1451535 & 0.05 & 0.961 & -.2774613 & .29153 \\
\hline q2weight । & .0646109 & .2340248 & 0.28 & 0.782 & -.3940693 & .5232911 \\
\hline q3weight | & .4214379 & .3102056 & 1.36 & 0.174 & -.186554 & 1.02943 \\
\hline q4weight | & -.2073589 & .3138343 & -0.66 & 0.509 & -.8224627 & .407745 \\
\hline q5weight | & .0524806 & .3144928 & 0.17 & 0.867 & -.5639139 & .6688751 \\
\hline SPD । & .4523049 & .1528363 & 2.96 & 0.003 & .1527512 & .7518585 \\
\hline $\mathrm{CDU} / \mathrm{CSU}$ । & -.407819 & .2641997 & -1.54 & 0.123 & -.9256408 & .1100028 \\
\hline GRUENE I & .1478482 & .4113574 & 0.36 & 0.719 & -.6583975 & .9540939 \\
\hline partystrong I & .2252564 & .3349402 & 0.67 & 0.501 & -.4312144 & .8817272 \\
\hline _cons I & -5.081945 & .5940192 & -8.56 & 0.000 & -6.246201 & -3.917689 \\
\hline
\end{tabular}




\section{Logit estimates union membership equation for subgroup of males}

\begin{tabular}{|c|c|c|c|c|c|c|}
\hline Logistic regression & & & & ber of obs & $=$ & 4275 \\
\hline & & & & $\operatorname{chi2}(30)$ & 247 & 0.37 \\
\hline & & & & $0>\operatorname{chi} 2$ & 0 . & 0000 \\
\hline Log likelihood $=-16$ & 8.2956 & & & udo R2 & 0 . & 4344 \\
\hline union | & Coef. & Std. Err. & $\mathrm{z}$ & $P>|z|$ & [95\% Conf. & Interval] \\
\hline fvacreal | & .0185199 & .0072704 & 2.55 & 0.011 & .0042701 & .0327697 \\
\hline umother I & 3.938591 & .1358613 & 28.99 & 0.000 & 3.672308 & 4.204874 \\
\hline foreign | & .0944331 & .2128064 & 0.44 & 0.657 & -.3226598 & .511526 \\
\hline tenure | & -.0312196 & .0163943 & -1.90 & 0.057 & -.0633518 & .0009125 \\
\hline tensqu । & .0013494 & .0004683 & 2.88 & 0.004 & .0004316 & .0022672 \\
\hline whitecollar | & -1.151196 & .1324413 & -8.69 & 0.000 & -1.410776 & -.8916155 \\
\hline berufsabschluss | & -.0857476 & .1153019 & -0.74 & 0.457 & -.3117351 & .1402399 \\
\hline hochschulabschluss | & -.2319451 & .2247995 & -1.03 & 0.302 & -.672544 & .2086538 \\
\hline teilzeit | & -.1131433 & .5634817 & -0.20 & 0.841 & -1.217547 & .9912605 \\
\hline tempconnew & -.2199541 & .2321085 & -0.95 & 0.343 & -.6748784 & .2349702 \\
\hline gr199 । & .9504135 & .1782725 & 5.33 & 0.000 & .6010058 & 1.299821 \\
\hline gr1999 | & 1.72015 & .1799308 & 9.56 & 0.000 & 1.367492 & 2.072808 \\
\hline gr2000 । & 2.012915 & .1797585 & 11.20 & 0.000 & 1.660595 & 2.365235 \\
\hline unemploymentrate | & .1015138 & .0189842 & 5.35 & 0.000 & .0643054 & .1387222 \\
\hline minen | & .5498592 & .3159383 & 1.74 & 0.082 & -.0693685 & 1.169087 \\
\hline manufacturing | & -.0623397 & .2064851 & -0.30 & 0.763 & -.467043 & .3423636 \\
\hline construction | & -.1001156 & .2108023 & -0.47 & 0.635 & -.5132806 & .3130494 \\
\hline trade I & -.115654 & .2792298 & -0.41 & 0.679 & -.6629343 & .4316263 \\
\hline transport | & .2980714 & .2727177 & 1.09 & 0.274 & -.2364454 & .8325883 \\
\hline bank I & -.174281 & .3471859 & -0.50 & 0.616 & -.8547529 & .506191 \\
\hline services I & .015139 & .2403703 & 0.06 & 0.950 & -.4559782 & .4862562 \\
\hline y89 । & -.2382316 & .0996647 & -2.39 & 0.017 & -.4335709 & -.0428923 \\
\hline q2weight | & -.0980056 & .1515452 & -0.65 & 0.518 & -.3950288 & .1990176 \\
\hline q3weight | & -.2030836 & .2322017 & -0.87 & 0.382 & -.6581905 & .2520234 \\
\hline q4weight | & -.2159558 & .2316804 & -0.93 & 0.351 & -.670041 & .2381293 \\
\hline q5weight | & -.2222543 & .2421458 & -0.92 & 0.359 & -.6968514 & .2523428 \\
\hline SPD I & .4003223 & .1015288 & 3.94 & 0.000 & .2013294 & .5993151 \\
\hline $\mathrm{CDU} / \mathrm{CSU}$ & -.1098729 & .1629029 & -0.67 & 0.500 & -.4291566 & .2094108 \\
\hline GRUENE | & .4875967 & .2772498 & 1.76 & 0.079 & -.0558029 & 1.030996 \\
\hline partystrong I & .4506872 & .1891678 & 2.38 & 0.017 & .079925 & .8214493 \\
\hline _cons I & -3.58239 & .4212633 & -8.50 & 0.000 & -4.408051 & -2.756729 \\
\hline
\end{tabular}




\section{Report of Stata's "mi impute" - tool}

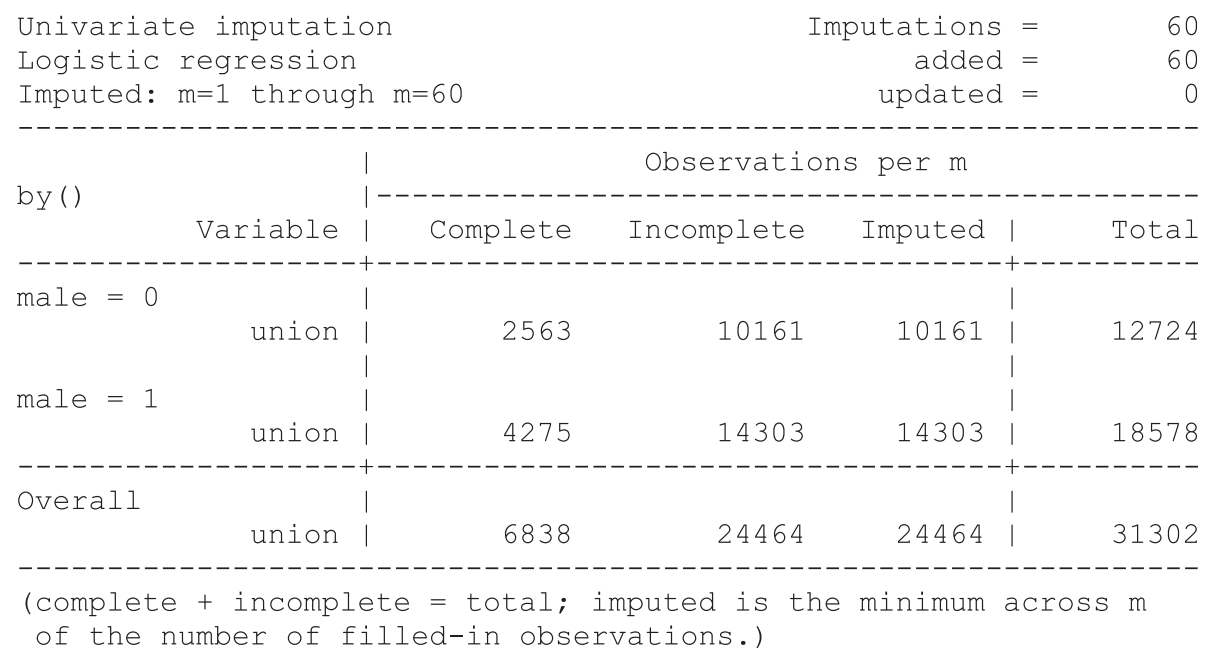

\section{Competing interests}

The IZA Journal of Labor Economics is committed to the IZA Guiding Principles of Research Integrity. The authors declare that they have observed these principles.

\section{Acknowledgement}

We are grateful for helpful comments by the editor, three anonymous referees, seminar audiences in Amsterdam and Trier, as well as participants of the CESifo area conference on Employment and Social Protection in München, the $11^{\text {th }}$ International German Socio-Economic Panel User Conference in Berlin and the $26^{\text {th }}$ annual meeting of the European Association of Labour Economists in Ljubljana. Furthermore, we acknowledge financial support from the Fritz Thyssen Stiftung under grant Az.10.10.1.082.

Responsible editor: Pierre Cahuc

\section{Author details}

${ }^{1}$ IAAEU - Trier University, Institute for Labour Law and Industrial Relations in the European Union, Campus II, D-54286 Trier, Germany. ${ }^{2}$ IZA, Bonn, Germany. ${ }^{3} \mathrm{CESifo}$, München, Germany. ${ }^{4}$ Department of Business and Economics, University of Applied Sciences Bielefeld, Interaktion 1, D 33619 Bielefeld, Germany. ${ }^{5}$ DIW, Berlin, Germany.

Received: 21 April 2015 Accepted: 4 August 2015

Published online: 10 September 2015

\section{References}

Alesina A, Glaeser E, Sacerdote B (2005) Work and leisure in the United States and Europe: why so different? NBER Macroecon Ann 20:1-64

Altonji JG, Usui E (2007) Work hours, wages, and vacation leave. Ind Labor Relat Rev 60(3):408-428

Berger T, Heylen F (2011) Differences in hours worked in the OECD, institutions or fiscal policies? J Money Credit Bank 43(7):1333-1369

Bryan ML (2006) Paid Holiday Entitlements, Weekly Working Hours and Earnings in the UK, ISER Working Paper 2006-52, University of Colchester

Bryson A and Forth J (2011), Trade Unions, 255-271, in: Gregg, Paul and Jonathan Wadsworth (eds), The Labour Market in Winter - the State of Working Britain. New York: Oxford University Press.

Buchmueller TC, DiNardo JE, Valetta RG (2004) A Submerging Labor Market Institution? Unions and Nonwage Aspects of Work, 231-263. In: Freeman RB, Hersch J, Mishel L (eds) Emerging Labor Market Institutions for the Twenty-First Century, University of Chicago Press

Buckley JE (1989) Variations in holidays, vacations, and area pay levels. Mon Labor Rev 112(2):24-30

Burgoon B, Baxandall P (2004) Three worlds of working time: the partisan and welfare politics of hours worked in industrialized countries. Polit Soc 32(4):439-473

Causa O (2009) The policy determinants of hours worked across OECD Countries, OECD Economic Studies., pp 1-39

Dardanoni V, Modica S, Peracchi F (2011) Regression with imputed covariates: a generalized missing-indicator approach. J Econometrics 162(2):362-368

Ellguth P, Kohaut S (2005) Tarifbindung und betriebliche Interessenvertretung: Aktuelle Ergebnisse aus dem IAB-Betriebspanel, WSI-Mitteilungen 7-2005., pp 398-403

Ellguth P, Kohaut S (2013) Tarifbindung und betriebliche Interessenvertretung - Ergebnisse aus dem IAB-Betriebspanel 2012, WSI-Mitteilungen 4-2013., pp 281-288 
Faggio G, Nickell S (2007) Patterns of work across the OECD. Econ J 117(521):F416-F440

Fakih A (2014) Vacation leave, work hours and wages: new evidence from linked employer-employee data. Labour 28(4):376-398

Fitzenberger B, Ernst M, Haggeney I (1999) Wer ist noch Mitglied in Gewerkschaften? Zeitschrift für Wirtschafts- und Sozialwissenschaften 119(2):223-263

Fitzenberger B, Kohn K, Wang Q (2011) The erosion of union membership in Germany: determinants, densities, decompositions. J Popul Econ 24(1):141-165

Freeman RB (1981) The effects of unionism on fringe benefits. Ind Labor Relat Rev 34(4):489-509

Goerke L, Pannenberg M (2004) Norm-based trade union membership: evidence for Germany. Ger Econ Rev 5(4):481-504

Goerke L, Pannenberg M (2011) Trade union membership and dismissals. Labour Econ 18(6):810-821

Goerke L, Pannenberg M (2015) Trade union membership and sickness absence: evidence from a sick pay reform. Labour Econ 33:13-25

Green F (1997) Union recognition and paid holiday entitlements. Br J Ind Relat 35(2):243-255

Green F, Potepan MJ (1988) Vacation time and unionism in the U.S. and Europe. Ind Relat 27(2):180-194

Maume DJ (2006) Gender differences in taking vacation time. Work Occup 33(2):161-190

OECD (2013), Employment Outlook 2013. Paris: OECD Publishing.

Oh S-Y, Park Y, Bowles S (2012) Veblen effects, political representation, and the reduction in working time over the 20th century. J Econ Behav Organ 83(2):218-242

Ohtake F (2003) Unions, the Costs of Job Loss and Vacation, 371-390. In: Ogura S, Tachibanaki T, Wise DA (eds) Labor Markets and Firm Benefit Policies in Japan and the United States, University of Chicago Press

Ray R, Sanes M, Schmitt J (2013) No-Vacation Nation Revisited, CEPR Report

Saborowski C (2005) Under-Utilisation of Holiday Entitlements as a Career Investment, DIW Research Notes 7

Seaman SR, White IR, Copas AJ, Li L (2012) Combining multiple imputation and inverse-probability weighting. Biometrics 68(1):129-137

Schmidt C, Zimmermann KF (1991) Work characteristics, firm size and wages. Rev Econ Stat 73(4):705-710

Schnabel C, Wagner J (2007) Union density and determinants of union membership in 18 EU countries: evidence from micro data, 2002/03. Ind Relat J 38(1):5-32

Schnitzlein DD (2012) Extent and effects of employees in Germany forgoing vacation time. DIW Econ Bull 2(2):25-31

Shi J, Skuterud M (2015) Gone fishing! reported sickness absenteeism and the weather. Econ Inq 53(1):388-405

Visser J (2013) ICTWSS: Database on Institutional Characteristics of Trade Unions, Wage Setting, State Intervention and Social Pacts in 34 Countries between 1960 and 2007. http://www.uva-aias.net/208, accessed December 13, 2013

Wagner GG, Frick JR, Schupp J (2007) The German Socio-Economic Panel Study (SOEP) - scope, evolution, and enhancements. Schmollers Jahrbuch 127(1):139-169

White IR, Royston P, Wood AM (2010) Multiple Imputation Using Chained Equations: Issues and Guidance for Practice. Stat Med 30(4):377-399

Wooldridge JM (2013) Correlated Random Effects Panel Data Models, IZA Summer School in Labor Economics. http://www.iza.org/conference_files/SUMS_2013/viewProgram?conf_id=2331

WSI (2014) Statistisches Taschenbuch - Tarifpolitik. http://www.boeckler.de/pdf/p_ta_tariftaschenbuch_2014.pdf; accessed June 20, 2014

\section{Submit your manuscript to a SpringerOpen ${ }^{\circ}$ journal and benefit from:}

- Convenient online submission

- Rigorous peer review

- Immediate publication on acceptance

- Open access: articles freely available online

- High visibility within the field

- Retaining the copyright to your article 